\title{
Nicotine Interactions with Haloperidol, Clozapine and Risperidone and Working Memory Function in Rats
}

Nii Addy, B.S., and Edward D. Levin, Ph.D.

Nicotine has been shown in a variety of studies to improve memory performance. The cognitive effects of nicotine are particularly important with regard to schizophrenia. In the current studies nicotine interactions with three different antipsychotic drugs, haloperidol, clozapine and risperidone, were assessed with regard to memory function. Female Sprague-Dawley rats were trained on the radial-arm maze to asymptotic levels of choice accuracy. They were then administered nicotine alone or in combination with haloperidol, clozapine or risperidone. Acute haloperidol $(0.04 \mathrm{mg} / \mathrm{kg})$ did not by itself affect memory performance. Co-administration of haloperidol with nicotine, however, decreased memory performance compared with nicotine administration in isolation. Acute clozapine (1.25 and 2.5 $\mathrm{mg} / \mathrm{kg}$ ) caused a significant memory impairment, an effect reversed by acute nicotine co-treatment. Risperidone (0.05 $\mathrm{mg} / \mathrm{kg}$ ), like haloperidol, did not by itself affect memory performance. Risperidone co-administration with nicotine, however, did significantly attenuate the improvement caused by nicotine administration in isolation. The similar interaction of haloperidol and risperidone with nicotine may be due to their common action of blocking $D_{2}$ receptors, $a$ mechanism of action not shared by clozapine. In contrast to the interaction of nicotine with haloperidol or risperidone, nicotine effectively reversed clozapine-induced memory impairment. These studies demonstrate interactions between nicotine and antipsychotic drugs in terms of memory, which may have important impacts on the treatment of schizophrenia.

[Neuropsychopharmacology 27:534-541, 2002] (C) 2002 American College of Neuropsychopharmacology. Published by Elsevier Science Inc.
KEY WORDS: Nicotine; Haloperidol; Clozapine; Risperidone; Memory; Radial-arm maze

A variety of experimental studies have demonstrated nicotinic effects in cognition. Nicotine and nicotine agonists have been shown to improve aspects of cognition in both experimental animals and humans (Buccafusco et al. 1996; Levin 1992; Levin et al. 1996b; Levin and Si-

From the Department of Psychiatry and Behavioral Sciences, Duke University Medical Center, Durham, NC.

Address correspondence to: Dr. Edward D. Levin, Department of Psychiatry, Neurobehavioral Research Laboratory, Box \#3412, Duke University Medical Center, Durham, NC 27710. Tel.: (919) 681-6273; Fax: (919) 681-3412; E-mail: edlevin@duke.edu

Received September 11, 2001; revised February 19, 2002; accepted February 28, 2002.

Online publication: $3 / 6 / 02$ at www.acnp.org/citations/ Npp030602263. mon 1998). In particular, nicotine has been shown to improve working memory performance. In previous work, acute and chronic nicotine administration led to working memory improvements in rats tested on the radial-arm maze. In chronic administration studies, these effects persisted for at least two weeks after drug administration ended. The nicotinic antagonist, mecamylamine, blocked the memory improvements of both chronic and acute nicotine administration (Levin et al. 1993; Levin and Russell 1992). Nicotinic systems play an important role in the neural basis of memory function.

Nicotinic systems interact with a variety of other neural systems, which may be important in the neural basis of memory function. Activation of nicotinic receptors leads to the downstream release of many neurotransmitters including acetylcholine, dopamine (DA), 
norepinephrine, serotonin, and glutamate (Wonnacott et al. 1989). DA in particular has been shown to be important for memory function (Levin 1988). Several studies have examined the role of DA in memory function as well as the interactive effects of nicotine and DA. Previous work in our laboratory has illustrated the importance of DA in cognitive function by showing that both nicotinic and DA antagonists cause working memory deficits in rats tested on the radial arm maze. Nicotinic and DA agonists, on the other hand, induced working memory improvements in rats (Levin and Eisner 1994; Levin et al. 1990; Levin and Rose 1992; McGurk et al. 1989a,b). In addition, nicotine and nicotinic agonists have been shown to increase DA release in the striatum and the nucleus accumbens (Brazell et al. 1990; el-Bizri and Clarke 1994; Grady et al. 1992). Thus, the data illustrate that nicotinic and DA interactions are important for memory function (Levin et al. 1996a). However, the mechanisms of these interactions and their effects on memory are still unclear (Levin et al. 1996a).

The aim of the current study was to further explore the memory effects of interactions between the nicotinic and DA systems. While our previous studies involved the use of selective DA receptor drugs, this study employed the use of three antipsychotic medications: haloperidol, clozapine and risperidone. Many previous studies have explored DA effects on memory by looking at the memory effects of antipsychotic medications, which often act as DA antagonists at specific DA receptors. Haloperidol, a typical antipsychotic, is characterized by its antagonistic binding at the $\mathrm{D}_{2}$ DA receptors. Clozapine, an atypical antipsychotic, binds to the $D_{4}$ DA receptor subtype 10 times as strongly as it binds to $\mathrm{D}_{2}$ receptors. It also differs from haloperidol in that it shows a high affinity for $5-\mathrm{HT}_{2}$ sites and a much lower affinity for $\mathrm{D}_{2}$ sites in the cerebral cortex and striatum (Matsubara et al. 1993). Risperidone, another atypical antipsychotic, also has a higher affinity for the $5-\mathrm{HT}_{2}$ receptor than for the $\mathrm{D}_{2}$ receptor (Hertel et al. 1996; Sumiyoshi et al. 1994). In fact, risperidone binds to the $5 \mathrm{HT}_{2}$ receptor 20 times as strongly as it binds to $\mathrm{D}_{2}$, though its binding to the $\mathrm{D}_{2}$ receptor is comparable to that of haloperidol (Leysen et al. 1988).

While these drugs affect multiple neurotransmitter systems and are not as specific as other DA antagonists, it is still important to understand the memory effects of these antipsychotic medications in their interaction with nicotine. Furthermore, the interaction of nicotine with DA antagonists is one that occurs frequently in certain human populations. Statistics indicate that almost $90 \%$ of schizophrenics smoke cigarettes (Hughes et al. 1986). Thus, these individuals who are taking antipsychotic medications are co-administering nicotine as well. Through this study, we seek to gain a better understanding of the memory effects of these drug interactions.

We hypothesize that nicotine and antipsychotic medications are interacting, via the nicotinic and DA systems, to induce downstream effects on memory. In line with our previous findings, we hypothesize that acute nicotine administration can improve memory performance. Furthermore, we expect that acute haloperidol will decrease memory performance while acute clozapine and acute risperidone will decrease memory performance to a smaller extent or not at all. Third, we hypothesize that acute nicotine can reverse cognitive impairments caused by these antipsychotic medications when co-administered with them. We tested these hypotheses through drug challenge studies in rats on the radial-arm maze.

\section{METHODS}

\section{Subjects}

A total of 47 adult female Sprague-Dawley rats were used in three experimental groups. The haloperidol group consisted of 12 animals, the clozapine group consisted of 24 animals, and the risperidone group consisted of 11 animals. The rats were housed three per cage and were on a reverse $12 \mathrm{~h}$ light/ $12 \mathrm{~h}$ dark cycle (lights off at 7:00 A.M.). The subjects were on ad lib feeding for one week and then kept at approximately $85 \%$ of ad lib levels. Testing took place during the dark cycle and the rats were fed daily after testing. These studies were conducted under protocols approved by the Duke University Animal Care and Use Committee conforming to internationally accepted standards of animal welfare.

\section{Radial-Arm Maze}

Cognitive tests were performed using a black, wooden 8 -arm radial maze. The maze was elevated $30 \mathrm{~cm}$ off the ground, with a central platform $35 \mathrm{~cm}$ in diameter and 8 arms each $10 \times 80 \mathrm{~cm}$. Each arm contained a food cup, at its terminal end, which was baited during testing with one half piece of Kellogg's Froot Loops ${ }^{\circledR}$ cereal. At the beginning of each trial, a $30-\mathrm{cm}$ opaque ring was placed on the central platform and a rat was placed inside the ring for $10 \mathrm{~s}$. Following this interval, the ring was removed and timing began. The rat was allowed to run on the maze until all eight arms were entered or until $300 \mathrm{~s}$ had passed. An arm entry was recorded when all four of the animal's legs had crossed the threshold of the arm. Choice accuracy was measured by entries to repeat (ETR), which was the number of arms entered until a repeat entry was made into an arm previously entered during the trial. 
Table 1. Nicotine-Haloperidol Dose Combinations

\begin{tabular}{lll}
\hline Nicotine & & \multicolumn{1}{c}{ Haloperidol } \\
\hline $0 \mathrm{mg} / \mathrm{kg}$ nicotine & + & $0 \mathrm{mg} / \mathrm{kg}$ haloperidol \\
$0.2 \mathrm{mg} / \mathrm{kg}$ nicotine & + & $0 \mathrm{mg} / \mathrm{kg}$ haloperidol \\
$0.4 \mathrm{mg} / \mathrm{kg}$ nicotine & + & $0 \mathrm{mg} / \mathrm{kg}$ haloperidol \\
$0 \mathrm{mg} / \mathrm{kg}$ nicotine & + & $0.04 \mathrm{mg} / \mathrm{kg}$ haloperidol \\
$0.2 \mathrm{mg} / \mathrm{kg}$ nicotine & + & $0.04 \mathrm{mg} / \mathrm{kg}$ haloperidol \\
$0.4 \mathrm{mg} / \mathrm{kg}$ nicotine & + & $0.04 \mathrm{mg} / \mathrm{kg}$ haloperidol \\
\hline
\end{tabular}

\section{Haloperidol-Nicotine Interactions}

After 18 training sessions on the radial arm maze, rats $(n=12)$ began the drug phase of the experiment. In all the studies the drugs were dissolved in saline and injected in a volume of $1 \mathrm{ml} / \mathrm{kg}$. Acute administration was carried out via subcutaneous injection 20 min prior to the maze trial. Nicotine and haloperidol were coadministered in doses containing $0,0.2$, or $0.4 \mathrm{mg} / \mathrm{kg}$ of nicotine combined with 0 or $0.04 \mathrm{mg} / \mathrm{kg}$ of haloperidol. The six drug combinations are shown in Table 1. Each animal was tested once on the radial arm maze with each of the six drug combinations, which were given as cocktails. Animals were tested every other day to allow for the drug to be broken down and eliminated and they were not run on the maze during washout days. In this experiment, drug treatments were counterbalanced. Drug doses were based on salt weight for both nicotine ditartrate (Sigma) and haloperidol $\mathrm{HCl}$ (OrthoMcNeil).

\section{Clozapine-Nicotine Interactions}

After 18 training sessions on the radial arm maze, rats $(n=24)$ began the drug phase of the experiment in the same manner as described above for the haloperidoltreated animals. Nicotine and clozapine were co-administered in doses containing $0,0.2$, or $0.4 \mathrm{mg} / \mathrm{kg}$ of nicotine with $0,1.25$, or $2.50 \mathrm{mg} / \mathrm{kg}$ of clozapine. The nine drug combinations are shown in Table 2.

The animals were tested in the same manner as those in the nicotine-haloperidol group, with a washout day

Table 2. Nicotine-Clozapine Dose Combinations

\begin{tabular}{lcc}
\hline Nicotine & & \multicolumn{1}{c}{ Clozapine } \\
\hline $0 \mathrm{mg} / \mathrm{kg}$ nicotine & + & $0 \mathrm{mg} / \mathrm{kg}$ clozapine \\
$0.2 \mathrm{mg} / \mathrm{kg}$ nicotine & + & $0 \mathrm{mg} / \mathrm{kg}$ clozapine \\
$0.4 \mathrm{mg} / \mathrm{kg}$ nicotine & + & $0 \mathrm{mg} / \mathrm{kg}$ clozapine \\
$0 \mathrm{mg} / \mathrm{kg}$ nicotine & + & $1.25 \mathrm{mg} / \mathrm{kg}$ clozapine \\
$0.2 \mathrm{mg} / \mathrm{kg}$ nicotine & + & $1.25 \mathrm{mg} / \mathrm{kg}$ clozapine \\
$0.4 \mathrm{mg} / \mathrm{kg}$ nicotine & + & $1.25 \mathrm{mg} / \mathrm{kg}$ clozapine \\
$0 \mathrm{mg} / \mathrm{kg}$ nicotine & + & $2.50 \mathrm{mg} / \mathrm{kg}$ clozapine \\
$0.2 \mathrm{mg} / \mathrm{kg}$ nicotine & + & $2.50 \mathrm{mg} / \mathrm{kg}$ clozapine \\
$0.4 \mathrm{mg} / \mathrm{kg}$ nicotine & + & $2.50 \mathrm{mg} / \mathrm{kg}$ clozapine \\
\hline
\end{tabular}

Table 3. Nicotine-Risperidone Dose Combinations

\begin{tabular}{lll}
\hline Nicotine & & \multicolumn{1}{c}{ Risperidone } \\
\hline $0 \mathrm{mg} / \mathrm{kg}$ nicotine & + & $0 \mathrm{mg} / \mathrm{kg}$ risperidone \\
$0.2 \mathrm{mg} / \mathrm{kg}$ nicotine & + & $0 \mathrm{mg} / \mathrm{kg}$ risperidone \\
$0.4 \mathrm{mg} / \mathrm{kg}$ nicotine & + & $0 \mathrm{mg} / \mathrm{kg}$ risperidone \\
$0 \mathrm{mg} / \mathrm{kg}$ nicotine & + & $0.05 \mathrm{mg} / \mathrm{kg}$ risperidone \\
$0.2 \mathrm{mg} / \mathrm{kg}$ nicotine & + & $0.05 \mathrm{mg} / \mathrm{kg}$ risperidone \\
$0.4 \mathrm{mg} / \mathrm{kg}$ nicotine & + & $0.05 \mathrm{mg} / \mathrm{kg}$ risperidone \\
\hline
\end{tabular}

in between testing. Once again, doses were based on salt weight for nicotine ditartrate (Sigma) and clozapine (Research Biochemical International). The drugs were administered as cocktails and the treatments were counterbalanced.

\section{Risperidone-Nicotine Interactions}

After 18 training sessions on the radial arm maze, these rats $(n=11)$ began the drug phase of the experiment in the same manner as mentioned above. Nicotine and risperidone were co-administered in doses of $0,0.2$, or 0.4 $\mathrm{mg} / \mathrm{kg}$ of nicotine with 0 or $0.05 \mathrm{mg} / \mathrm{kg}$ of risperidone. The six drug combinations are shown in Table 3.

As in the two previous groups, doses for nicotine ditartrate (Sigma) and risperidone (Research Biochemical International) were based on salt weights. Drugs were administered in a cocktail and treatments were counterbalanced with a washout day between testing.

\section{Data Analysis}

The choice accuracy and response latency measures were assessed by a within-subjects design ANOVA. The factors were Nicotine and Antipsychotic dose. A $p$-value of less than .05 was considered significant. The tests were two-tailed except to test a one-tailed hypothesis to verify the previously demonstrated nicotine-induced memory improvement (for review see Levin and Simon (1998)). A control between-subjects factor of high or low pretest performance accuracy was used to reduce variability and test whether there were selective drug effects on good or poor performers. In analyzing data from each of the three studies, planned comparisons were made between vehicle only administration (saline) and each of the antipsychotic doses alone. Planned comparisons were also made between each of the antipsychotic doses alone with the two doses of nicotine.

\section{RESULTS}

\section{Haloperidol-Nicotine Interactions}

There was a significant main effect of haloperidol $\left(\mathrm{F}_{1,10}=\right.$ 9.97, $p<.025)$. However, as can be seen in Figure 1 , 
Nicotine-Haloperidol Interactions Radial-Arm Maze Accuracy

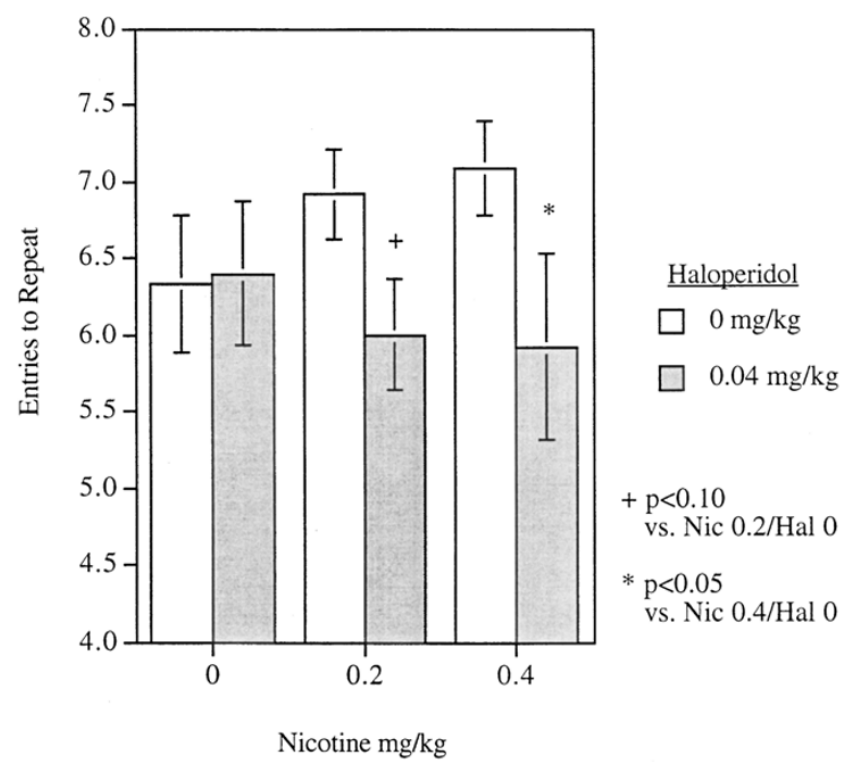

Figure 1. Haloperidol interactions with nicotine and radial-arm maze working memory performance, Entries to Repeat (mean \pm SEM).

there was no effect of haloperidol on working memory performance detected in the absence of nicotine. Nicotine administration without haloperidol produced a significant $(p<.05)$ improvement in working memory performance as has been seen many times previously (for review see Levin and Simon (1998)). The haloperidol-induced deficit was seen when it was given in combination with nicotine. With the higher nicotine dose $(0.4 \mathrm{mg} / \mathrm{kg})$, haloperidol co-treatment caused a significant $(p<.05)$ decrease in working memory performance compared with $0.4 \mathrm{mg} / \mathrm{kg}$ of nicotine alone. A similar but not quite significant $(p<.10)$ effect was seen with haloperidol reducing performance accuracy with $0.2 \mathrm{mg} / \mathrm{kg}$ of nicotine.

Latency was significantly increased by haloperidol as evidenced by the significant main effect of haloperidol $(\mathrm{F} 1,11)=5.71, p<.05)$. The main effect of nicotine and the haloperidol $\mathrm{X}$ nicotine interaction were not significant. Interestingly, despite the fact that there was a significant main effect of haloperidol, haloperidol treatment alone did not significantly increase latency relative to the saline control condition. Rather, haloperidol co-treatment reversed the significant $(p<.05)$ reductions in latency caused by $0.2 \mathrm{mg} / \mathrm{kg}$ and $0.4 \mathrm{mg} / \mathrm{kg}$ of nicotine.

\section{Clozapine-Nicotine Interactions}

Both doses of clozapine significantly impaired choice accuracy when administered alone $(p<.025)$. The 0.4

\section{Nicotine-Clozapine Interactions Radial-arm Maze Choice Accuracy}

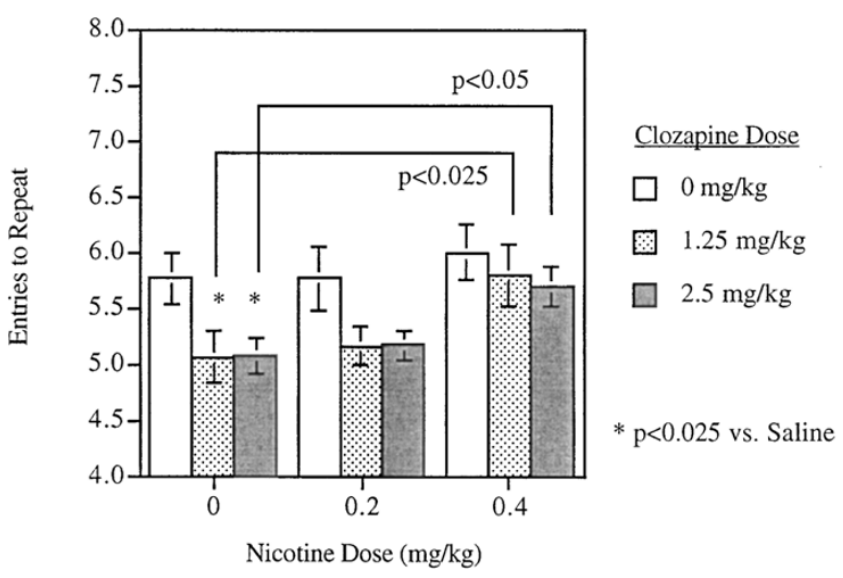

Figure 2. Clozapine interactions with nicotine and radialarm maze working memory performance, Entries to Repeat (mean \pm SEM).

dose of nicotine significantly reversed the memory impairment caused by $1.25 \mathrm{mg} / \mathrm{kg}$ of clozapine $(p<.025)$ and $2.5 \mathrm{mg} / \mathrm{kg}$ of clozapine $(p<.05)$, returning choice accuracy to nearly control levels. The lower dose of $0.2 \mathrm{mg} /$ $\mathrm{kg}$ of nicotine was not effective in reversing the clozapineinduced impairment (Figure 2). A higher acute injection dose of $5 \mathrm{mg} / \mathrm{kg}$ of clozapine was tested in pilot studies, but it caused excessive sedation and was not used in further studies.

Latency was significantly increased by clozapine as detected by a significant clozapine main effect $\left(\mathrm{F}_{2,46}=\right.$ $6.08, p<.005)$. The main effect of nicotine and the clozapine $\mathrm{X}$ nicotine interaction were not significant. However, neither dose of clozapine by itself significantly affected latency relative to performance after saline injection. The combination of the $2.5 \mathrm{mg} / \mathrm{kg}$ clozapine dose with either $0.2 \mathrm{mg} / \mathrm{kg}(p<.01)$ or $0.4 \mathrm{mg} / \mathrm{kg}$ nicotine $(p<.05)$ significantly increased latency compared with these doses on nicotine alone.

\section{Nicotine-Risperidone Interactions}

In the nicotine-risperidone experiment (Figure 3) there was a significant nicotine main effect $\left(\mathrm{F}_{2,18}=8.85, p<\right.$ $.005)$ with regard to choice accuracy $(n=11)$. The interaction of nicotine $X$ risperidone was significant $\left(\mathrm{F}_{2,18}=\right.$ $4.06, p<.05)$. The planned comparisons showed that the $0.4 \mathrm{mg} / \mathrm{kg}$ nicotine dose caused a significant $(p<$ .001) improvement in working memory performance compared with the saline treatment. The rats averaged $5.20 \pm 0.52$ entries to repeat after saline injections and $7.27 \pm 0.03$ entries to repeat after $0.4 \mathrm{mg} / \mathrm{kg}$ of nicotine. The rats averaged an intermediate $6.30 \pm 0.41$ entries to repeat after the lower dose of $0.2 \mathrm{mg} / \mathrm{kg}$ of nicotine, 
Nicotine-Risperidone Interactions Radial-Arm Maze Accuracy

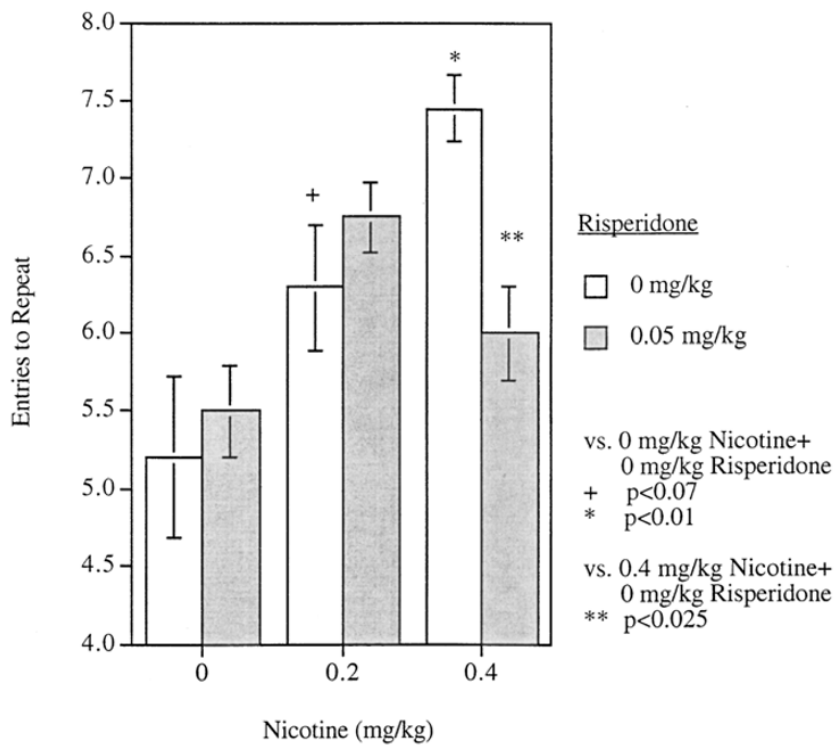

Figure 3. Risperidone interactions with nicotine and radial-arm maze working memory performance, Entries to Repeat (mean \pm SEM).

however this improvement was not quite significant $(p<$ $.071)$. Risperidone $(0.05 \mathrm{mg} / \mathrm{kg})$ did not impair performance relative to saline. In fact there was a slight, though nonsignificant, increase in the entries to repeat measure to $5.50 \pm 0.29$. However this dose of risperidone did significantly attenuate the memory improvement caused by nicotine $(0.4 \mathrm{mg} / \mathrm{kg})$. The entries to repeat measure dropped from $7.45 \pm 0.21$ with $0.4 \mathrm{mg} / \mathrm{kg}$ of nicotine alone to $6.00 \pm 0.30$ with $0.4 \mathrm{mg} / \mathrm{kg}$ of nicotine $+0.05 \mathrm{mg} / \mathrm{kg}$ of risperidone, a significant difference $(p<.025)$. A higher acute risperidone injection dose of $0.1 \mathrm{mg} / \mathrm{kg}$ was tested in pilot studies, but it caused excessive sedation, so that choice accuracy could not be reliably determined.

There was a significant main effect of risperidone on latency $\left(\mathrm{F}_{1,10}=7.62, p<.025\right)$. The nicotine main effect and the nicotine $X$ risperidone interaction were not significant. The $0.05 \mathrm{mg} / \mathrm{kg}$ risperidone dose caused a significant $(p<.05)$ increase in latency that was reversed by co-administration of $0.2 \mathrm{mg} / \mathrm{kg}$ of nicotine $(p<.025)$. The $0.4 \mathrm{mg} / \mathrm{kg}$ nicotine dose modestly decreased the risperidone-induced sedation, but this was not significant.

\section{DISCUSSION}

The data presented in this study points to the interaction of nicotine and DA in working memory function. We found that acute clozapine, at $1.25 \mathrm{mg} / \mathrm{kg}$ and 2.50 $\mathrm{mg} / \mathrm{kg}$, caused a significant working memory deficit in rats on the radial-arm maze. In contrast, acute haloperi- dol administration at $0.04 \mathrm{mg} / \mathrm{kg}$ and acute risperidone, at $0.05 \mathrm{mg} / \mathrm{kg}$ did not cause a significant impairment. Both acute haloperidol and acute risperidone, however, blocked any nicotine-induced improvement in working memory performance. Nicotine, however, reversed the working memory impairment induced by acute clozapine administration of 1.25 or $2.5 \mathrm{mg} / \mathrm{kg}$. Together, these results illustrate the different memory effects of antipsychotic administration either in isolation or in combination with nicotine.

While we hypothesized that acute nicotine administration would induce improvement in memory performance, we observed variation in the nicotinic effect in the three experiments we performed. Nicotine induced improvement was most clearly observed in the nicotine-risperidone experiment. As illustrated in the results, animals in the nicotine-risperidone experiment receiving nicotine at a dose of $0.4 \mathrm{mg} / \mathrm{kg}$ showed a significant increase in memory performance compared with saline administration. In the nicotine-haloperidol experiment, nicotine at $0.4 \mathrm{mg} / \mathrm{kg}$ produced a smaller increase in memory performance. The difference in nicotine's effect may be due to the fact that the saline administration trials in these two experiments resulted in different baseline levels. In the nicotine-risperidone experiment, the ETR value following saline administration was lower than the same value in the nicotine-haloperidol group. Thus, in the nicotine-haloperidol study, the animals were performing at higher levels with saline treatment and had less room for improvement. In the nicotine-clozapine experiment, we also did not observe a nicotine-induced memory improvement. This may have been due to negative carry-over effects of the clozapine treatment in the repeated measures design.

We also hypothesized that acute haloperidol would cause a decrease in memory performance, but this effect was not observed in the study. Previous work in our laboratory has shown that chronic haloperidol decreases memory performance in both rats and humans (Levin et al. 1996a, 1987; Levin 1997). Thus, the memory effects of acute haloperidol administration in the current study differ from chronic haloperidol administration studies previously carried out in our lab (Levin 1997). In the current study, we also hypothesized that acute nicotine would reverse memory impairments caused by any of the three antipsychotics tested. In the nicotine-haloperidol experiment, however, we observed that haloperidol blocked responsiveness to the $0.4 \mathrm{mg} / \mathrm{kg}$ dose of nicotine (see Figure 1).

Given prior memory related research carried out with risperidone, we hypothesized that acute risperidone would decrease memory performance to a lesser extent than haloperidol or not at all. Acute risperidone administration has been shown to induce both improvements in a working memory task in rats and increased frontal cortical activity in schizophrenics dur- 
ing a working memory task (Honey et al. 1999; Nowakowska et al. 1999). In the current nicotine-risperidone experiment, acute risperidone administration in isolation did not induce a significant change in memory performance in rats on the radial-arm maze. Acute risperidone, however, did block the nicotine induced memory improvement.

The results from the nicotine-haloperidol and nicotine-risperidone experiments suggest that blockade of the $\mathrm{D}_{2}$ receptor affects nicotinic and DA interactions in memory performance on the radial arm maze. In interpreting the downstream memory effects of nicotinic and DA interactions in these two experiments, it is important to consider the binding properties of haloperidol and risperidone. Though both drugs have affinity for the $D_{2}$ receptor, haloperidol's affinity for the receptor is two to three times stronger than that of risperidone in vitro. In addition, haloperidol administration results in quick $D_{2}$ occupancy while risperidone administration leads to gradual $\mathrm{D}_{2}$ occupancy (Schotte et al. 1996). In light of these differences in $D_{2}$ affinity and their effects on DA, one would expect that haloperidol would be more likely to induce memory impairment than risperidone. In addition, if nicotine exerts its memory effects through downstream DA activity, one could hypothesize that $\mathrm{D}_{2}$ antagonism by haloperidol would block the nicotinic improvement effect more than antagonism with risperidone. It is also important to note that the memory effects of risperidone may also be due to its antagonism at other receptors, namely the $5 \mathrm{HT}_{2}$ receptor. Risperidone binds to the $5 \mathrm{HT}_{2 \mathrm{~A}}$ receptor 20 times as strongly as it binds to $\mathrm{D}_{2}$ in vivo (Schotte et al. 1996). Thus, this $5 \mathrm{HT}_{2 \mathrm{~A}}$ antagonism may play a role in the downstream release of neurotransmitters that affect memory. From the results in the current study, however, we conclude that there is an important interaction between nicotinic and DA systems in memory function that appears to be partially mediated through the $\mathrm{D}_{2}$ receptor.

In the nicotine-clozapine experiment, acute clozapine administration induced a significant decrease in memory performance, contrasting with our hypothesis that it would induce slight memory impairment or none at all. In line with part of our hypothesis, however, nicotine did reverse the clozapine-induced memory impairment. The results from this experiment with acute clozapine administration contrast with previous studies where chronic clozapine administration led to less of a cognitive impairment effect than chronic haloperidol (Buchanan et al. 1994; Hagger et al. 1993). In addition, clozapine administration in humans, in comparison to typical neuroleptics, has also been shown to cause greater improvement in certain cognitive tests including verbal fluency, psychomotor speed, and attention (Lee et al. 1999; Meltzer and McGurk 1999). These differing memory effects may be due to differing phar- macodynamic characteristics of acute versus chronic administration of these drugs. Previous work in other laboratories also illustrates other possible mechanisms by which clozapine may have induced the memory impairment we observed in the current study. For instance, previous studies showed that clozapine inhibited nicotine binding at nicotine acetylcholine receptors and also inhibited downstream catecholamine secretion (Park et al. 2001). This inhibition of the nicotinic acetylcholine receptors by clozapine and the downstream effects could lead to memory impairment such as we observed. In addition, this interpretation is consistent with previous work in our lab, which showed that acute administration of nicotinic receptor antagonists in the hippocampus caused memory impairment (Levin et al. 2002). In light of this interpretation, our observation that nicotine reverses clozapine-induced impairment suggests that acute clozapine-induced limitation of nicotinic receptor binding is not sufficient to block nicotine-induced improvement.

The results from the nicotine-clozapine experiment also illustrate the importance of DA in working memory function and suggest that DA receptor binding at the $\mathrm{D}_{4}$ receptor is one of contributing factors. Clozapine, in contrast to many of the typical antipsychotic medications, has a higher affinity for the $\mathrm{D}_{4}$ receptor than the $\mathrm{D}_{2}$ receptor (Schotte et al. 1996). This strong affinity for the $\mathrm{D}_{4}$ receptor may also contribute to its therapeutic effectiveness (Liegeois et al. 1998). While acute clozapine antagonism causes memory impairment, which is blocked by nicotine, it is difficult to make direct correlation to specific neurotransmitter systems because clozapine affects so many systems. In fact, clozapine, like many atypical antipsychotic medications, has a higher affinity for the $5 \mathrm{HT}_{2 \mathrm{~A}}$ receptor than the $\mathrm{D}_{2}$ receptor in vivo (Schotte et al. 1996). In addition, clozapine also has high binding affinities for specific histamine and muscarinic receptors and both of these systems are involved in memory function (Kathmann et al. 1994; Michal et al. 1999; Roussinov and Yonkov 1976; Wall et al. 2001). Because clozapine does affect other neurotransmitter systems as well, it would be helpful to further explore the involvement of the $D_{4}$ receptor by using a drug that is more specific for this receptor subtype.

Although we explored the effects of nicotinic interaction with acute clozapine, it would be interesting and helpful to also look at nicotinic interaction with chronic clozapine administration. Our observation that acute clozapine caused a working memory deficit was actually somewhat surprising given that clozapine has been noted to have less cognitive impairment effects than typical antipsychotics (Buchanan et al. 1994; Hagger et al. 1993). As mentioned earlier, this effect may be due to pharmacodynamic differences with acute versus chronic administration. Thus, it would be useful to look at chronic clozapine administration in 
rats to see whether working memory impairments are observed or not.

This study and studies like it are important as we seek to understand not only memory function, but nicotinic involvement in memory function as well. With the complexity of nicotinic activity in the brain, we are continuing to explore how nicotine is acting to affect memory. This study further supports previous work that nicotinic and DA interaction is important in working memory function. It is clear that altering activity in these systems through nicotinic and antipsychotic administration leads to downstream effects on memory performance. Further studies will allow us to continue to explore how much of a role each system plays in memory function. Furthermore, this allows us to improve our understanding of which DA receptor subtypes are important.

Understanding the interactions of nicotinic and DA systems in memory function carries many important implications. Since such a large proportion of people with schizophrenia smoke cigarettes, it is important for us to understand the memory effects of this co-administration. In addition, looking at nicotinic involvement in memory provides clues to possible treatments for illnesses with cognitive deficit components, such as Alzheimer's and Parkinson's disease. Characterization of nicotinic interactions with DA systems is an important endeavor for improved treatment of cognitive dysfunction and for improvement of the basic understanding of the neural basis of cognitive function.

\section{ACKNOWLEDGMENTS}

This work was supported by National Institute on Drug Abuse grant \# DA 11943 and a grant from the National Alliance for Research on Schizophrenia and Depression. We do not have conflict of interests with the makers of these antipsychotic drugs.

\section{REFERENCES}

Brazell MP, Mitchell SN, Joseph MH, Gray JA (1990): Acute administration of nicotine increases the in vivo extracellular levels of dopamine, 3.4-dihydroxyphenylacetic acid and ascorbic acid preferentially in the nucleus accumbens of the rat: Comparison with caudate-putamen. Neuropharmacology 29:1177-1185

Buccafusco JJ, Prendergast MA, Terry AV, Jackson WJ (1996): Cognitive effects of nicotinic cholinergic receptor agonists in nonhuman primates. Drug Develop Res. 38:196-203

Buchanan RW, Holstein C, Breier A (1994): The comparative efficacy and long-term effect of clozapine treatment on neuropsychological test performance. Biol Psychiatry 36:717-725

el-Bizri H, Clarke PBS (1994): Blockade of nicotinic receptor- mediated release of dopamine from striatal synaptosomes by chlorisondamine administered in vivo. Br J Pharmacol 111:414-418

Grady S, Marks MJ, Wonnacott S, Collins AC (1992): Characterization of nicotinic receptor-mediated $\mathrm{H}^{3}$ dopamine release from synaptosomes prepared from mouse striatum. J Neurochem 59:848-856

Hagger C, Buckley P, Kenny JT, Friedman L, Ubogy D, Meltzer HY (1993): Improvement in cognitive functions and psychiatric symptoms in treatment-refractory schizophrenic patients receiving clozapine. Biol Psychiatry 34:702-712

Hertel P, Nomikos GG, Iurlo M, Svensson TH (1996): Risperidone: regional effects in vivo on release and metabolism of dopamine and serotonin in the rat brain. Psychopharmacology (Berl) 124:74-86

Honey GD, Bullmore ET, Soni W, Varatheesan M, Williams SC, Sharma T (1999): Differences in frontal cortical activation by a working memory task after substitution of risperidone for typical antipsychotic drugs in patients with schizophrenia. Proc Natl Acad Sci USA 96:1343213437

Hughes JR, Hatsukami DK, Mitchell JE, Dahlgren LA (1986): Prevalence of smoking among psychiatric outpatients. Am J Psychiatry 143:993-997

Kathmann M, Schlicker E, Gothert M (1994): Intermediate affinity and potency of clozapine and low affinity of other neuroleptics and of antidepressants at $\mathrm{H} 3$ receptors. Psychopharmacology (Berl) 116:464-468

Lee MA, Jayathilake K, Meltzer HY (1999): A comparison of the effect of clozapine with typical neuroleptics on cognitive function in neuroleptic-responsive schizophrenia. Schizophr Res 37:1-11

Levin E, Wilson W, Rose J, McEvoy J (1996a): Nicotine-haloperidol interactions and cognitive performance in schizophrenics. Neuropsychopharmacology 15:429-436

Levin ED (1988): Psychopharmacological effects in the radial-arm maze. Neurosci Biobehav Rev 12:169-175

Levin ED (1992): Nicotinic systems and cognitive function. Psychopharmacology (Berl) 108:417-431

Levin ED (1997): Chronic haloperidol administration does not block acute nicotine-induced improvements in radial-arm maze performance in the rat. Pharmacol Biochem Behav 58:899-902

Levin ED, Bradley A, Addy N, Sigurani N (2002): Hippocampal $\alpha 7$ and $\alpha 4 \beta 2$ nicotinic receptors and working memory. Neuroscience 104:757-765

Levin ED, Briggs SJ, Christopher NC, Rose JE (1993): Chronic nicotinic stimulation and blockade effects on working memory. Behav Pharmacol 4:179-182

Levin ED, Eisner B (1994): Nicotine interactions with D1 and D2 agonists: Effects on working memory function. Drug Dev Res 31:32-37

Levin ED, Galen D, Ellison GD (1987): Chronic haloperidol effects on radial arm maze performance and oral movements in rats. Pharmacol Biochem Behav 26:1-6

Levin ED, McGurk SR, Rose JE, Butcher LL (1990): Cholinergic-dopaminergic interactions in cognitive performance. Behav Neural Biol 54:271-299

Levin ED, Rose JE (1992): Cognitive effects of $D_{1}$ and $D_{2}$ 
interactions with nicotinic and muscarinic systems. In Levin ED, Decker MW, Butcher LL (eds), Neurotransmitter Interactions and Cognitive Function. Boston, Berkhäuser, pp 144-158

Levin ED, Rose JE, Lippelio P, Robinson J (1996b): Nicotine and neurobehavioral function. Drug Develop Res 38:135

Levin ED, Russell RW (1992): Nicotinic-muscarinic interactions in cognitive function. In Levin ED, Decker MW, Butcher LL (eds), Neurotransmitter Interactions and Cognitive Function. Boston, Berkhäuser, pp 183-195

Levin ED, Simon BB (1998): Nicotinic acetylcholine involvement in cognitive function in animals. Psychopharmacology (Berl) 138:217-230

Leysen JE, Gommeren W, Eens A, de Chaffoy de Courcelles D, Stoof JC, Janssen PA (1988): Biochemical profile of risperidone, a new antipsychotic. J Pharmacol Exp Ther 247:661-70

Liegeois J, Eyrolles L, Bruhwyler J, Delarge J (1998): Dopamine D4 receptors: a new opportunity for research on schizophrenia. Curr Med Chem 5:77-100

Matsubara S, Matsubara R, Kusumi I, Koyama T, Yamashita I (1993): Dopamine D1, D2 and serotonin2 receptor occupation by typical and atypical antipsychotic drugs in vivo. J Pharmacol Exp Ther 265:498-508

McGurk SR, Levin ED, Butcher LL (1989a): Nicotinicdopaminergic relationships and radial-arm maze performance in rats. Behav Neural Biol 52:78-86

McGurk SR, Levin ED, Butcher LL (1989b): Radial-arm maze performance in rats is impaired by a combination of nicotinic-cholinergic and $\mathrm{D}_{2}$ dopaminergic drugs. Psychopharmacology (Berl) 99:371-373

Meltzer HY, McGurk SR (1999): The effects of clozapine, risperidone, and olanzapine on cognitive function in schizophrenia. Schizophr Bull 25:233-255
Michal P, Lysikova M, El-Fakahany E, Stanislav T (1999): Clozapine interaction with the M2 and M4 subtypes of muscarinic receptors. Eur J Pharmacol 376:119-125

Nowakowska E, Chodera A, Kus K, Rybakowski J (1999): Some behavioural effects of risperidone in rats: comparison with haloperidol. Eur Neuropsychopharmacol 9:421-426

Park T, Bae S, Choi S, Kang B, Kim K (2001): Inhibition of nicotinic acetylcholine receptors and calcium channels by clozapine in bovine adrenal chromaffin cells. Biochem Pharmacol 31:1011-1019

Roussinov K, Yonkov D (1976): Effect of imidazole, papeverine and histamine on learning and memory in albino rats. Acta Physiol Pharmacol Bulg 2:49-57

Schotte A, Janssen PF, Gommeren W, Luyten WH, Van Gompel P, Lesage AS, De Loore K, Leysen JE (1996): Risperidone compared with new and reference antipsychotic drugs: in vitro and in vivo receptor binding. Psychopharmacology (Berl) 124:57-73

Sumiyoshi T, Kido H, Sakamoto H, Urasaki K, Suzuki K, Yamaguchi N, Mori H, Shiba K, Yokogawa K (1994): In vivo dopamine-D2 and serotonin-5-HT2 receptor binding study of risperidone and haloperidol. Pharmacol Biochem Behav 47:553-557

Wall P, Flinn J, Messier C (2001): Infralimbic muscarinic M1 receptors modulate anxiety-like behaviors and spontaneous working memory in mice. Psychopharmacology (Berl) 155:58-68

Wonnacott S, Irons J, Rapier C, Thorne B, Lunt GG (1989): Presynaptic modulation of transmitter release by nicotinic receptors. In Nordberg A, Fuxe K, Holmstedt B, Sundwall A (eds), Progress In Brain Research. New York, Elsevier Science Publishers B.V., pp 157-163 